\title{
Global warming and amphibian extinctions in eastern Australia
}

\author{
WILLIAM F. LAURANCE \\ Smithsonian Tropical Research Institute, Apartado 0843-03092, Balboa, Ancón, Republic of Panama \\ (Email: laurancerv@si.edu)
}

\begin{abstract}
Pounds et al. recently argued that the dramatic, fungal pathogen-linked extinctions of numerous harlequin frogs (Atelopus spp.) in upland rainforests of South America mostly occurred immediately following exceptionally warm years, implicating global warming as a likely trigger for these extinctions. I tested this hypothesis using temperature data for eastern Australia, where at least 14 upland-rainforest frog species have also experienced extinctions or striking population declines attributed to the same fungal pathogen, and where temperatures have also risen significantly in recent decades. My analyses provide little direct support for the warm-year hypothesis of Pounds et al., although my statistical power to detect effects of small $\left(0.5^{\circ} \mathrm{C}\right)$ temperature increases was limited. However, I found stronger support for a modified version of the warm-year hypothesis, whereby frog declines were likely to occur following three consecutive years of unusually warm weather. This trend was apparent only at tropical latitudes, where rising minimum temperatures were greatest. Although much remains uncertain, my findings appear consistent with the notion that global warming could predispose some upland amphibian populations to virulent pathogens.
\end{abstract}

Key words: amphibian decline, chytrid fungus, climate change, epidemic disease, frog, Queensland, rainforest, species extinction.

\section{INTRODUCTION}

One of the most alarming environmental trends in recent decades has been the sudden declines and disappearances of amphibians throughout the world. Many declines are driven by habitat destruction or degradation, but others have occurred in habitats that appear largely pristine (Blaustein \& Wake 1995; Alford \& Richards 1999; Stuart et al. 2004). In the tropics and subtropics of the New World, Australia, and other regions, as many as 200 amphibian species have abruptly disappeared or declined precipitously at higher elevations, mostly involving species associated with streams and in environments with few apparent human impacts (Speare \& Berger 2004; Stuart et al. 2004; Skerratt et al. 2007). These declines are frequently attributed to a waterborne, chytrid-fungus pathogen (Batrachochytrium dendrobatidis) that is highly virulent to many amphibian species (e.g. Berger et al. 1998; Daszak et al. 1999, 2003; Lips 1999; Longcore et al. 1999; Lips et al. 2003, 2006; Woodhams et al. 2003; Retallick et al. 2004; Weldon et al. 2004). It is not yet known, however, if the fungus is an emerging pathogen that is being transported among continents via international trade, or a widespread, endemic microparasite that has suddenly become highly virulent as amphibians are affected by some environmental change

Accepted for publication July 2007. or stressor (see Alford \& Richards 1999; Rachowicz \& Vredenburg 2004; McCallum 2005; Oullet et al. 2005; Skerratt et al. 2007 for discussion).

Pounds et al. (2006) recently demonstrated an apparently high degree of synchrony between increasing temperatures at tropical latitudes and sudden extinctions of many locally endemic harlequin frogs (Atelopus spp.) scattered across the Andean Mountains of South America. Their main conclusion - that most of these extinctions occurred immediately after unusually warm years, which likely provided favourable growth conditions for the chytrid pathogen - was accepted uncritically in the accompanying introduction in Nature (Blaustein \& Dobson 2006) and in most of the subsequent media coverage (e.g. Morelle 2006). This work is already becoming established in the technical literature as an important example of the far-reaching impacts of global warming (e.g. Lovejoy 2006; Thomas et al. 2006). To quote the senior author of Pounds et al. (2006), 'Disease is the bullet killing frogs, but climate change is pulling the trigger' (Morelle 2006).

Some, however, have been more sceptical of this interpretation, citing the correlative nature of Pounds et al.'s analysis and other concerns (e.g. Watson 2006). Moreover, in Panama and Costa Rica, amphibian declines attributed to the chytrid pathogen have shown no apparent association with annual temperature or other weather variables, but are spreading in a wave-like 
Table 1. Characteristics of weather stations used in the analysis of amphibian declines in eastern Australia

\begin{tabular}{|c|c|c|c|c|}
\hline Station & Elevation (m) & Latitude/longitude & Years of analysis & $n$ \\
\hline Nambour $^{\dagger}$ & 25 & $26^{\circ} 39^{\prime} \mathrm{S}, 152^{\circ} 56^{\prime} \mathrm{E}$ & 1954-1979 & 22 \\
\hline Mackay & 30 & $21^{\circ} 07^{\prime} \mathrm{S}, 149^{\circ} 13^{\prime} \mathrm{E}$ & 1960-1985 & 26 \\
\hline Cairns & 3 & $16^{\circ} 53^{\prime} \mathrm{S}, 145^{\circ} 45^{\prime} \mathrm{E}$ & 1943-1989 & 47 \\
\hline
\end{tabular}

$n=$ number of years included in analyses, including the year that frog populations initially began declining.

${ }^{\dagger}$ Data unavailable for $1959-1960$ and $1963-1964$.

pattern consistent with the expected behaviour of a highly virulent epidemic (Lips et al. 2006). Amphibian declines in eastern Australian rainforests also seem to have propagated in a wave-like pattern (Laurance et al. 1996), although this interpretation has been challenged (Alford \& Richards 1997; Alford et al. 2007).

Other researchers have disputed specific elements of the Pounds et al. (2006) hypothesis, while generally supporting their view that global warming could predispose amphibians to disease. Di Rosa et al. (2007) suggested that pathogens other than the chytrid fungus could be involved in climate-linked epidemics of amphibians. Alford et al. (2007) found evidence of increasing fluctuating asymmetry (FA), an indicator of developmental stress, in limb dimensions of two frog species (Litoria nannotis and Litoria genimaculata) that experienced chytrid-related population declines in north Queensland. They detected rising FA in the 15-19 months before the known onset of population declines, and suggested that this reflected increasing stress (possibly from rising temperatures) that then predisposed frog populations to the chytrid pathogen. Because the two Litoria species require 1-2 years to reach maturity, Alford et al. (2007) asserted that their findings implied an increase in stress beginning at least 2 years before the onset of chytrid-related population declines, rather than merely during the year preceding the decline, as originally postulated by Pounds et al. (2006).

My colleagues and I were among the first to argue that a rapidly spreading, epidemic pathogen was responsible for widespread amphibian declines, basing our analyses on the abrupt extinctions or population declines of 14 rainforest frog species across a $1500-\mathrm{km}$ expanse of eastern Australia (Laurance et al. 1996, 1997). This presumptive pathogen was later identified as the same chytrid fungus associated with amphibian declines elsewhere in the world (Berger et al. 1998). Given the prominence of the Pounds et al. (2006) study and its potentially important implications for understanding global amphibian declines, I elected to test the generality of their climate-linked epidemic hypothesis using long-term weather data for eastern Australia. I also evaluated a modified version of the Pounds et al. hypothesis that was suggested by the recent findings of Alford et al. (2007).

\section{METHODS}

\section{Amphibian declines}

Amphibian declines in eastern Australian rainforests have been actively studied since 1979, when five frog species including the unique southern gastricbrooding frog (Rheobatrachus silus) suddenly began to vanish or decline drastically in south-eastern Queensland (Corben 1991; Covacevich \& McDonald 1993; Ingram \& McDonald 1993). These declines were followed by the abrupt disappearance of two frog species in central-eastern Queensland (McDonald 1990) in 1985, and extinctions or major declines of seven frog species in north-eastern Queensland (Richards et al. 1993; Trenerry et al. 1994; Laurance et al. 1996; McDonald \& Alford 1999) beginning in 1989. All of the declining species or populations occur in upland or montane rainforests ( $>400 \mathrm{~m}$ elevation), and all are strongly associated with streams as larvae and often as adults (Laurance et al. 1996; Williams \& Hero 1998). I previously assessed the effects of selected weather (especially rainfall) parameters on these declines (Laurance 1996), but did not evaluate the hypothesis that the single year preceding frog declines was atypically warm (defined as Pounds et al. 2006 as having unusually high minimum temperatures).

\section{Weather stations}

I collected temperature data from weather stations situated very near to the actual locations of amphibian declines (Table 1). A total of 17 weather stations was examined but most lacked continuous (or nearly continuous) long-term data on mean monthly maximum and minimum temperatures for periods of at least 20 years before the observed frog declines. However, the Nambour, Mackay and Cairns stations are near the rainforest tracts where frog declines occurred in southeastern Queensland (Connondale Ranges), centraleastern Queensland (Eungella area) and north-eastern Queensland (Townsville-Cooktown Wet Tropics area), respectively. At these localities, observed large-scale frog declines initially occurred in 1979 (south-eastern 
Table 2. Data used to test whether the year immediately preceding large-scale frog declines in eastern Australia had either an atypically high mean minimum temperature (Hypothesis 1 ) or an atypically low mean maximum temperature (Hypothesis 2 ), as originally proposed by Pounds et al. (2006)

Hypothesis 1: The year preceding frog declines had an atypically high mean minimum temperature

\begin{tabular}{|c|c|c|c|c|c|c|c|c|}
\hline \multirow[b]{2}{*}{ Station } & \multicolumn{3}{|c|}{ Baseline interval } & \multirow[b]{2}{*}{$\mu$} & \multirow[b]{2}{*}{$Z=(\mu-\overline{\mathrm{X}}) / \mathrm{SD}$} & \multirow[b]{2}{*}{$P$} & \multicolumn{2}{|c|}{ Statistical power $(\%)$} \\
\hline & $\mathrm{N}$ & $\overline{\mathrm{X}}$ & SD & & & & $0.5^{\circ}$ & $1.0^{\circ}$ \\
\hline Nambour & 20 & 13.669 & 0.873 & 13.633 & 0.0409 & 0.516 & 23.9 & 44.6 \\
\hline Mackay & 24 & 18.723 & 0.495 & 18.925 & 0.4085 & 0.342 & 39.3 & 77.1 \\
\hline Cairns & 45 & 20.665 & 0.444 & 21.392 & 1.6356 & 0.051 & 43.8 & 83.4 \\
\hline
\end{tabular}

Hypothesis 2: The year preceding frog declines had an atypically low mean maximum temperature

\begin{tabular}{lcccccccc} 
& \multicolumn{3}{c}{ Baseline interval } & & & & \multicolumn{2}{c}{ Statistical power (\%) } \\
\cline { 2 - 4 } Station & $\mathrm{N}$ & $\overline{\mathrm{X}}$ & $\mathrm{SD}$ & $\mu$ & $Z=(\mathrm{X}-\mu) / \mathrm{SD}$ & $P$ & $0.5^{\circ}$ & $1.0^{\circ}$ \\
\hline Nambour & 20 & 25.506 & 0.375 & 25.125 & 1.0155 & 0.155 & 52.0 & 91.7 \\
Mackay & 24 & 26.164 & 0.283 & 26.300 & -0.4804 & 0.685 & 68.6 & 98.8 \\
Cairns & 45 & 28.839 & 0.298 & 29.592 & -2.2583 & 0.994 & 65.5 & 98.1 \\
\hline
\end{tabular}

Shown for each hypothesis and weather station are the number of years of available data $(\mathrm{N})$ for the baseline interval, the mean $(\overline{\mathrm{X}})$ and standard deviation (SD) of temperatures for that interval, the mean temperature $(\mu)$ for the year immediately preceding frog declines, the appropriate formula for calculating $Z$, and the probability value $(P)$ for each one-tailed $Z$-test. Also shown is the statistical power of each test to detect temperature differences of $0.5^{\circ}$ and $1.0^{\circ} \mathrm{C}$, using a critical alpha of 0.10 .

Queensland), 1985 (central-eastern Queensland) and 1989 (north-eastern Queensland), as described above.

All three weather stations are Class I Australian Bureau of Meteorology sites, and thus are subject to rigorous maintenance and regular calibration of sensors. The three stations are all in the lowlands (Table 1) but should, nonetheless, provide reasonable data on interannual temperature trends in nearby upland forests. For example, the mean daily maximum temperature at the lowland weather station at Cairns (elevation $=3 \mathrm{~m})$ was a strong predictor $\left(F_{1,23}=21.92\right.$, $\left.R^{2}=48.8 \%, P=0.0001\right)$ of this same parameter in the nearby uplands at Kairi (elevation $=502 \mathrm{~m}$ ), using data for 25 years (1953-1956 and 1965-1985) in which values were recorded at both stations. The same was true for mean daily minimum temperatures $\left(F_{1,22}=11.38, R^{2}=34.1 \%, P=0.0027\right.$; linear regressions with untransformed data).

\section{Statistical methods}

The main prediction of Pounds et al. (2006) is that the year in which frogs declined at any location should be preceded by a year with an atypically high mean minimum temperature (Hypothesis 1). They further proposed that the chytrid pathogen was favoured by low mean maximum temperatures in the year preceding frog declines (Hypothesis 2), which they suggest could occur if rising tropical temperatures increase cloud cover at higher elevations. To test Hypothesis 1, I calculated for each weather station the mean minimum temperature for a baseline interval (encompassing all years preceding the year before frog declines occurred), pooled these data to generate a distribution of minimum-temperature values, and then estimated the likelihood that the year before the decline was warmer than the baseline interval, using a one-tailed, one-sample $Z$-test. A comparable procedure was used to test Hypothesis 2, but using a different formula to calculate $Z$ (Table 2). Baseline temperatures did not deviate significantly $(P>0.05)$ from normality in any case (Wilk-Shapiro tests), so data transformations were not used.

I also tested modified versions of the two Pounds et al. (2006) hypotheses, as suggested by the recent conclusions of Alford et al. (2007). For this analysis, I tested for a predicted increase in mean minimum temperatures across a 3-year interval, which included the year of frog declines and the 2 years immediately preceding it, relative to all earlier years (Hypothesis 1-modified). A similar procedure was used to test for a predicted decline in mean maximum temperatures across the same 3-year interval (Hypothesis 2-modified). For each weather station, analyses were conducted using a one-tailed, two-sample $t$-test.

To assess the likelihood of Type II statistical errors (the probability of failing to reject a false null hypothesis), I conducted power analyses for my tests of the original and modified versions of Hypotheses 1 and 2 at each weather station. For these analyses, statistical power is a consequence of four factors: the magnitude of the difference between samples (also known as the 'effect size'), the sample sizes, the standard deviations 
(SDs) of the samples, and the critical alpha $(P)$ value used in the statistical test (Cohen 1988; Nackagawa 2004). I evaluated statistical power for two effect sizes, of 0.5 and $1.0^{\circ} \mathrm{C}$, which span the range of meantemperature differences observed by Pounds et al. (2006; fig. 4b) between baseline years and the years preceding amphibian declines in South America. To provide acceptable statistical power (see below), I used a relatively liberal, a priori alpha value of 0.10 for the $Z$-tests, and the standard alpha (0.05) for the $t$-tests. For the $Z$-tests, power was calculated using Systat Version 11 with a sample size of 1 and the observed $\mathrm{SD}$ for all years in the predecline interval. For the $t$-tests, power was calculated with DSS Researcher's Toolkit (http://www.dssresearch.com/toolkit/spcalc/ power_a2.asp), using the corresponding sample sizes and SDs for the predecline and decline intervals.

For each hypothesis, results from the three different weather stations were combined using Fisher's log-probability test (Magurran 1998), where $\chi^{2}=-2$ $(\ln [P 1]+\ln [P 2]+\ln [P 3]), P_{i}$ are the probability values from each test, and $\chi^{2}$ is evaluated at 6 degrees of freedom. This allowed me to integrate separate analyses from the three weather stations into a single, overall test of each hypothesis.

\section{RESULTS}

\section{Trends in temperature}

It is important to emphasize that the Pounds et al. (2006) hypothesis is plausible because, at least at tropical latitudes, minimum (night-time) temperatures did in fact tend to increase over time in the years preceding frog declines in eastern Australia (Fig. 1). There were significant, positive correlations between the year and mean annual minimum temperatures in tropical Mackay $\left(r_{\mathrm{s}}=0.425, P=0.031\right)$ and tropical Cairns $\left(r_{\mathrm{s}}=0.297, \mathrm{P}=0.043\right)$, but not in subtropical Nambour $\left(r_{\mathrm{s}}=-0.273, P=0.22\right)$. However, there was no significant correlation between year and mean annual maximum temperature at any of the weather stations (Nambour: $r_{\mathrm{s}}=0.071, P=0.75$; Mackay: $r_{\mathrm{s}}=0.244, P=0.23$; Cairns: $r_{\mathrm{s}}=0.174, P=0.24$; all Spearman rank tests, based on 22, 26 and 47 years of data for Nambour, Mackay and Cairns, respectively; Table 1).

\section{The original hypotheses}

The $Z$-tests of the original Hypothesis 1 by Pounds et al. (that frog declines should begin following years with high mean minimum temperatures) yielded probability values of $0.516,0.342$ and 0.051 for Nambour,

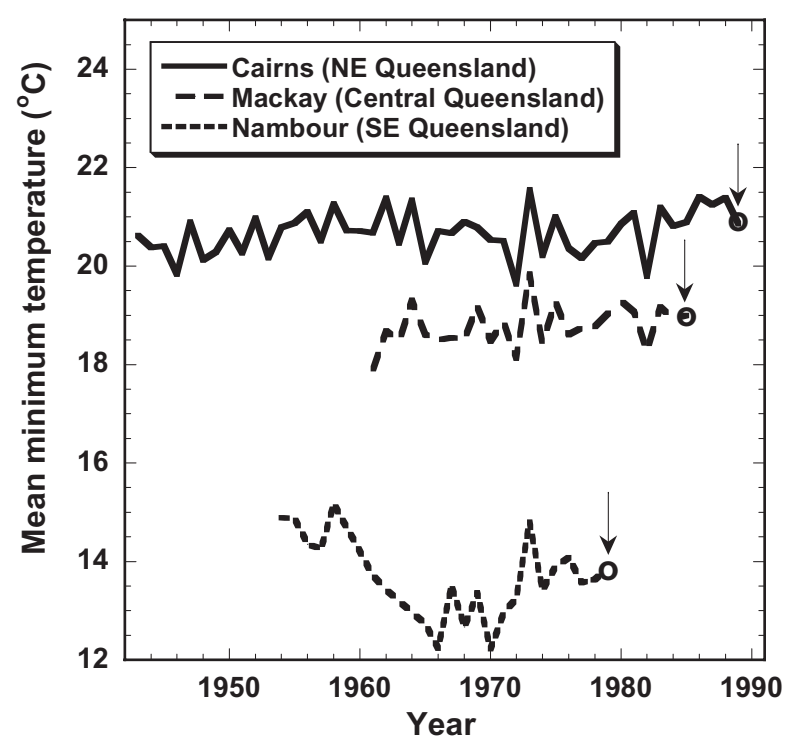

Fig. 1. Mean annual minimum temperatures for three lowland weather stations near major rainforest tracts in Queensland, Australia in the years before and during the onset of dramatic frog declines. For each area, the arrow and circle indicate the year in which large-scale declines were first observed.

Mackay and Cairns, respectively (Table 2). Hence, large-scale frog declines commenced after a relatively warm year at Cairns, but not at the other two localities. However, when these three independent tests of the same hypothesis were combined into a single analysis, results were non-significant $(P=0.151$, d.f. $=6$, $\chi^{2}=9.42 ;$ Fisher's Log-Probability Test), thereby failing to provide clear support for the warm-year hypothesis of Pounds et al. (2006).

Results for Hypothesis 2 of Pounds et al. (that frog declines should begin following years with low mean maximum temperatures) were all non-significant, yielding probability values of $0.155,0.685$ and 0.994 for Nambour, Mackay and Cairns, respectively (Table 2). The overall test of Hypothesis 2 was also non-significant $\left(P=0.608\right.$, d.f. $=6, \chi^{2}=4.50$; Fisher's Log-Probability Test).

Two further permutations of this analysis also failed to yield significant results. First, for both Hypothesis $1(P=0.188)$ and Hypothesis $2(P=0.750)$, frog declines were not effectively predicted by using the annual averages of monthly extreme temperature minima and maxima, rather than monthly mean minima and maxima (Fisher's Log-Probability Tests). In this analysis none of the tests of individual weather stations was significant $(P>0.11$ in all cases; onetailed $Z$-tests). Second, results were non-significant for Hypothesis $1 \quad(P=0.389)$ and Hypothesis 2 $(P=0.970)$ when I tested for atypical temperatures in the year that large-scale frog declines actually began near each weather station, rather than in the year 
Table 3. Tests of modified hypotheses of temperature effects on rainforest amphibians, as suggested by the findings of Alford et al. (2007)

\begin{tabular}{|c|c|c|c|c|c|c|c|c|c|}
\hline \multirow[b]{3}{*}{ Station } & \multicolumn{9}{|c|}{$\begin{array}{c}\text { Hypothesis 1-Modified: Mean minimum temperature in the 3-year interval immediately } \\
\text { before and during decline was unusually warm }\end{array}$} \\
\hline & \multicolumn{2}{|c|}{ Baseline interval } & \multicolumn{2}{|c|}{ Decline interval } & \multirow[b]{2}{*}{$t$} & \multirow[b]{2}{*}{ d.f. } & \multirow[b]{2}{*}{$P$} & \multicolumn{2}{|c|}{ Statistical power $(\%)$} \\
\hline & $\overline{\mathrm{X}}$ & $\mathrm{SD}$ & $\overline{\mathrm{X}}$ & SD & & & & $0.5^{\circ}$ & $1.0^{\circ}$ \\
\hline Nambour $^{\dagger}$ & 13.674 & 0.872 & 13.683 & 0.114 & -0.17 & 19.8 & 0.435 & 76.6 & 99.9 \\
\hline Mackay & 18.704 & 0.485 & 19.031 & 0.101 & -1.12 & 24 & 0.137 & 99.6 & 100 \\
\hline \multirow[t]{3}{*}{ Cairns } & 20.652 & 0.435 & 21.167 & 0.226 & -1.99 & 45 & 0.027 & 96.3 & 100 \\
\hline & \multicolumn{9}{|c|}{$\begin{array}{l}\text { Hypothesis 2-Modified: Mean maximum temperature in the 3-year interval immediately } \\
\text { before and during decline was unusually cool }\end{array}$} \\
\hline & \multicolumn{2}{|c|}{ Baseline interval } & \multicolumn{2}{|c|}{ Decline interval } & & & & \multicolumn{2}{|c|}{ Statistical power $(\%)$} \\
\hline Station & $\overline{\mathrm{x}}$ & SD & $\overline{\mathrm{X}}$ & SD & $t$ & d.f. & $P$ & $0.5^{\circ}$ & $1.0^{\circ}$ \\
\hline Nambour & 25.478 & 0.353 & 25.669 & 0.394 & -0.82 & 20 & 0.789 & 66.6 & 99.4 \\
\hline Mackay & 26.151 & 0.276 & 26.465 & 0.137 & -1.86 & 24 & 0.963 & 100 & 100 \\
\hline Cairns & 28.833 & 0.295 & 29.231 & 0.258 & -2.22 & 45 & 0.984 & 94.2 & 100 \\
\hline
\end{tabular}

Shown for each hypothesis and weather station are the mean $(\overline{\mathrm{X}})$ and standard deviation (SD) of annual mean temperatures during the baseline and population-decline intervals, and the test statistic $(t)$, degrees of freedom (d.f) and probability value $(P)$ for one-tailed $t$-tests of each hypothesis. Also shown is the statistical power of each test to detect temperature differences of $0.5^{\circ}$ and $1.0^{\circ} \mathrm{C}$, using a standard critical alpha $(P=0.05)$.

${ }^{\dagger} \mathrm{A} t$-test for unequal variances was used, because variances differed significantly between the predecline and decline intervals.

immediately preceding those declines. As before, none of the tests of individual weather stations was significant $(P>0.28$ in all cases; one-tailed $Z$-tests).

\section{The modified hypotheses}

The $t$-tests of the modified version of Hypothesis 1 (that mean minimum temperatures should be elevated in the 3-year period before and during the onset of frog declines) were non-significant for Nambour ( $P=$ $0.435)$ and Mackay $(P=0.137)$, but significant for Cairns $(P=0.027)$, suggesting, at least for the latter region, that Hypothesis 1-modified was supported (Table 3). Moreover, the overall test of Hypothesis 1 -modified was significant $(P=0.045$, d.f. $=6$, $\chi^{2}=12.89$; Fisher's Log-Probability Test), suggesting that a series of years with unusually high minimum temperatures did predispose amphibians to population declines. This pattern was largely driven by trends at tropical latitudes; for the cumulative $\chi^{2}$ test statistic used in Fisher's Log-Probability Test, just $13 \%$ of the total value was provided by subtropical Nambour, whereas $31 \%$ and $56 \%$ of the total was provided by tropical Mackay and Cairns, respectively.

However, there was no support for the modified version of Hypothesis 2 (that mean maximum temperatures should be lower in the 3-year period during and before the onset of frog declines). $P$-values for $t$-tests were $0.789,0.963$ and 0.984 for Nambour, Mackay and Cairns, respectively (Table 3), and the overall test of Hypothesis 2-modified was far from significant $\left(P=0.997\right.$, d.f. $=6, \chi^{2}=0.58$; Fisher's Log-Probability Test).

\section{Statistical power}

For my hypothesis tests at the individual weather stations, statistical power was variable (Tables 2,3). For a small effect size $\left(0.5^{\circ} \mathrm{C}\right)$, power was relatively low on average $(36 \%)$ for tests of the original Hypothesis 1 , but better $(62 \%)$ for the original Hypothesis 2. For a larger effect size $\left(1.0^{\circ} \mathrm{C}\right)$, average power improved considerably for both Hypothesis $1(68 \%)$ and Hypothesis $2(96 \%)$. As a rule of thumb, statistical power of $80 \%$ or higher is desirable (Cohen 1988), although many published studies have lower power (Jennions \& Møller 2002).

For the modified versions of the two hypotheses, statistical power was very good even for a small effect size $\left(0.5^{\circ} \mathrm{C}\right)$, averaging $91 \%$ and $90 \%$ for Hypothesis 1-modified and Hypotheses 2-modified, respectively. For a larger effect size $\left(1.0^{\circ} \mathrm{C}\right)$, power was excellent, averaging $98-100 \%$ for both hypotheses (Table 3).

My power analyses related to hypothesis tests at the three individual weather stations. For each hypothesis, I also integrated results from the three stations into a single, overall analysis, using Fisher's Log-Probability tests. I am aware of no formal power analysis for this latter test, but numerical simulations provide some insights into the statistical power available. For the test 
of the original Hypothesis 1, results would be significant $(P=0.05)$ if the mean minimum temperature in the year preceding frog declines $(\mu)$ was in the upper $12 \%$ of observations at all three weather stations. Alternatively, results would be significant if $\mu$ at one station was in the upper $5 \%$ of observations and $\mu$ values at the other stations were in the upper $19 \%$ of observations. Finally, if $\mu$ at one station was in the upper $1 \%$ of observations, then the overall test would be significant if $\mu$ values at the remaining stations were in the upper $42 \%$ of observations. Results were identical for Hypothesis 2.

\section{DISCUSSION}

\section{Statistical limitations}

My findings seem most consistent with a modified version of the main hypothesis of Pounds et al. (2006), in which higher mean minimum temperatures are thought to predispose upland amphibian populations to epidemic disease, potentially by providing more optimal growth conditions for a virulent chytrid pathogen (see Pounds et al. 2006 for discussion). The impetus for my modified version of the Pounds et al. hypothesis comes from Alford et al. (2007), who suggested that, for two frog species in north Queensland, evidence of increased stress was detectable at least 2 years before their observed population declines. I therefore tested for unusual temperature trends during a 3-year interval immediately before and during the known onset of declines.

Although my modified hypothesis is consistent with the ongoing-stress hypothesis of Alford et al. (2007), there are at least two alternative explanations for my findings. First, the statistical protocol I used to evaluate my modified hypothesis (Table 3) was more powerful than that for the original Pounds et al. hypothesis (Table 2), particularly for small effect sizes $\left(0.5^{\circ} \mathrm{C}\right)$, and thus more likely to yield a significant result. Second, my analysis assumes that Australian investigators correctly detected the year of onset of frog declines at each of the three rainforest tracts I studied. This is especially important for the original Pounds et al. hypothesis, which requires contrasting temperatures in the single year immediately preceding declines with those in previous years. The temporal and spatial pattern of large-scale rainforest amphibian declines was perhaps better documented in eastern Australia than anywhere else in the world, both in populous south-eastern Queensland and adjoining areas (e.g. Corben 1991; Covacevich \& McDonald 1993; Ingram \& McDonald 1993; Mahony 1993) and in central and northern Queensland, where investigators were actively monitoring frog populations at the time that declines occurred (e.g. McDonald 1990; Richards et al. 1993; Trenerry et al. 1994; Laurance et al. 1996; Hero \& Gillespie 1997; McDonald \& Alford 1999). Nevertheless, because it focuses on temperature trends within the single year preceding amphibian declines, the Pounds et al. hypothesis is more sensitive to minor disparities between the actual and observed onset of population crashes at any locality.

Assessing the effects of temperature variation on amphibian declines in eastern Australia is a statistical challenge, in part because the 14 upland species known to have declined or disappeared were found within just three discrete rainforest tracts, and thus cannot be considered independent observations. Indeed, Alford et al. (2007) argued that such an analysis was infeasible because of the small number of rainforest tracts and limited weather stations in the region with long-term temperature data. I obviously disagree, although it is apparent that the statistical approach used by Pounds et al. (2006), who assessed frog declines at a far larger number of montane sites in South America, would not have been appropriate in eastern Australia. My statistical constraints were increased by the fact that I was attempting to discern atypical temperature trends during a narrow window of time (1-3 years) immediately before or during the onset of frog declines, which greatly limited the sample sizes available for analysis. I also was forced to infer interannual temperature trends at higher elevations using nearby lowland weather stations (Table 1). Although this would have introduced some statistical 'noise' into the analysis, I see no reason to believe it created any systematic biases. In fact, my use of local weather-station data probably provided a better estimate of nearby annual mean temperatures than did the approach of Pounds et al. (2006), who inferred annual temperature trends across the vast Andean Mountain chain using air- and sea-surface data collected at a coarse, pan-tropical scale $\left(30^{\circ} \mathrm{S}\right.$ to $\left.30^{\circ} \mathrm{N}\right)$.

\section{Further caveats}

Although my findings are consistent with a modified version of the main Pounds et al. (2006) hypothesis, four caveats are in order. First, the overall test of this hypothesis was only marginally significant $(P=0.045)$; one would be more comfortable heralding these findings if the trend was stronger. Second, my significant result was largely driven by trends at tropical latitudes, where minimum (night-time) temperatures rose significantly in the years preceding frog declines. Third, my analyses, like those of Pounds et al. (2006), are correlative in nature, and thus cannot demonstrate a clear causal relationship between warming trends and amphibian declines. Finally, I found no support for the 
ancillary hypothesis of Pounds et al. (2006), which suggests that declining mean maximum temperatures should also help to trigger amphibian declines.

My findings suggest that upland frog declines coincided with rising annual minimum temperatures in eastern Australia, at least in the tropics. Notably, I previously tested for possible effects of temperature (and rainfall) trends on amphibian declines in eastern Australia, using the same weather stations and datasets as in this analysis, and concluded that these were unlikely to be responsible for the observed declines (Laurance 1996). Why am I now drawing a differing conclusion? First, my earlier analysis focused mostly on rainfall trends, for which long-term data from a far larger number of weather stations were available. Second, my original analyses were performed without the benefit of any a priori hypotheses about how temperature might affect amphibian declines or amphibian-pathogen interactions (indeed, at that time, the notion that a pathogen was involved in largescale amphibian declines was highly controversial; see Alford \& Richards 1997 and Hero \& Gillespie 1997; and the response by Laurance et al. 1997). As a consequence, in my earlier analysis I used two-tailed statistical tests, which are more conservative than the one-tailed tests used to test specific hypotheses in this study. Finally, in my previous study I did detect a moderately excessive number of atypically warm months in the 5-year period preceding frog declines, especially at tropical latitudes in summer (Laurance 1996). However, I concluded that this was unlikely to explain the observed declines, because the declining frog species would almost certainly have survived roughly comparable conditions at other times during their long evolutionary history; because local crashes of rainforest frog populations had occurred throughout the year, not just during the warmer summer months (see also Skerratt et al. 2007); and because at that time there was no known reason why warm months should affect only stream-dwelling frogs while leaving many other frog species unaffected (Laurance 1996).

\section{Points of debate}

It is important to emphasize that much remains unknown about the dynamics of spread of the chytrid pathogen, about the potential impacts of other amphibian pathogens (e.g. Di Rosa et al. 2007), and about the nature of climate-pathogen interactions. Many researchers, for example, remain unconvinced that ongoing disease-linked amphibian declines are being widely instigated by rising global temperatures or associated climatic variables (e.g. Lips et al. 2006; S. Cashins et al. pers. comm. 2006), as proposed by
Pounds et al. (2006). Another key point of debate concerns the degree to which chytrid-linked population crashes have followed a wave-like pattern of geographical spread (see Alford \& Richards 1997, 1999; Alford et al. 2007), as has been asserted in eastern Australia (Laurance et al. 1996, 1997) and Central America (Lips et al. 2006), where declines have been especially well studied. This latter debate may bear on another fundamental disagreement: whether the chytrid is a rapidly spreading, emerging pathogen that is being transported around the world by human agency, or a widespread, endemic microparasite whose virulence has suddenly increased because amphibian immune responses are being suppressed by some environmental stressor (see McCallum 2005 and Skerratt et al. 2007 for excellent summaries). A wave-like pattern is more consistent with that expected from an emerging pathogen.

Although unresolved, three lines of evidence appear to militate against the idea that the chytrid fungus (B. dendrobatidis) is simply an endemic pathogen that opportunistically attacks stressed amphibians. First, chytrid-linked amphibian declines have been documented on several continents and at varying times (e.g. Lips et al. 2003; Bell et al. 2004; Speare \& Berger 2004; Stuart et al. 2004), and to date no single environmental stressor has been identified that can easily account for these numerous population crashes (see Laurance et al. 1997; Alford \& Richards 1999; McCallum 2005; Rachowicz \& Vredenburg 2005; Lips et al. 2006 for differing perspectives). Second, low genetic variation (few nucleotide polymorphisms) among $B$. dendrobatidis sampled from many geographical areas is consistent with the idea of an emerging clonal pathogen that has been recently and widely introduced, although further analyses are required to draw definitive conclusions (Morehouse et al. 2003). Finally, immunosuppressed host species are usually affected by a number of opportunistic pathogens, but analyses of 147 wild and captive frogs suffering from chytridiomycosis in Australia indicated that only one showed any evidence of opportunistic pathogens or immunosuppression (Berger et al. 1999).

In my personal view, it stretches plausibility to argue that the chytrid pathogen is simply an opportunistic, endemic microparasite that has suddenly begun causing catastrophic species declines as a consequence of contemporary global warming (see also Skerratt et al. 2007). The recent warming trends were simply not that exceptional (Fig. 1), relative to the marked climatic vicissitudes the affected frog species would have encountered over geological timescales (Laurance 1996). If global warming is predisposing upland amphibians to disease, it is most likely operating in concert with an emerging pathogen of remarkable virulence. It is possibly a trigger in certain contexts, but not the bullet itself.

doi:10.1111/j.1442-9993.2007.01812.x 


\section{CONCLUSIONS}

There is little doubt that global warming could alter the geographical ranges of many pathogens (Epstein 2001; Harvell et al. 2002). The results of my study are consistent with the notion that dramatic amphibian declines in eastern Australia coincided with multiyear intervals of high minimum temperatures, at least at tropical latitudes. However, because of unavoidable statistical constraints and the marginally significant nature of my results, these findings should be interpreted with some caution.

There is, of course, a dire need to better understand the nature and dynamics of chytrid-linked amphibian declines, given the exceptional peril it evidently poses for many amphibians (Daszak et al. 2003; Lips et al. 2006; Mendelson et al. 2006; Skerratt et al. 2007). Bioclimatic modelling suggests that the potential geographical range of $B$. dendrobatidis is very extensive (Ron 2005), implying that it may continue to cause many additional amphibian declines and extinctions around the world. The deleterious impacts on biodiversity could be even greater if the range and activity of the chytrid pathogen is being further increased by global warming.

\section{ACKNOWLEDGEMENTS}

I thank Alan Pounds, Karen Lips, Stephen Williams, Stephen Turton, Jean-Marc Hero, Peter Daszak and Andrew Crawford for extensive discussion and comments on the paper.

\section{REFERENCES}

Alford R. A. \& Richards S. J. (1997) Lack of evidence for epidemic disease as an agent in the catastrophic decline of Australian rain forest frogs. Conserv. Biol. 11, 1026-9.

Alford R. A. \& Richards S. J. (1999) Global amphibian declines: a problem in applied ecology. Annu. Rev. Ecol. Syst. 30, 133-65.

Alford R. A., Bradfield K. S. \& Richards S. J. (2007) Global warming and amphibian losses. Nature 447, E3-E4.

Bell B. D., Carvers S., Mitchell N. J. \& Pledger S. (2004) The recent decline of a New Zealand endemic: how and why did populations of Archey's frog Leiopelma archeyi crash over 1996-2001? Biol. Conserv. 120, 193-203.

Berger L., Speare R., Daszak P. et al. (1998) Chytridiomycosis causes amphibian mortality associated with population declines in the rain forests of Australia and Central America. Proc. Natl. Acad. Sci. USA 95, 9031-6.

Berger L., Speare R. \& Hyatt A. (1999) Chytrid Fungi and Amphibian Declines: Overview, Implications and Future Directions. Environment Australia, Canberra.

Blaustein A. R. \& Dobson A. (2006) A message from the frogs. Nature 439, 143-4.
Blaustein A. R. \& Wake D. B. (1995) The puzzle of declining amphibian populations. Sci. Am. 272, 52-7.

Cohen J. (1988) Statistical Power Analysis for the Behavioral Sciences, 2nd edn. Erlbaum, Hillsdale.

Corben C. J. (1991) Comments on Frog Decline in South East Queensland, Unpublished Report. Queensland Nat. Parks Wildl. Service, Brisbane.

Covacevich J. A. \& McDonald K. R. (1993) Distribution and conservation of frogs and reptiles of Queensland rainforests. Mem. Qld. Mus. 34, 189-99.

Daszak P., Berger L., Cunningham A. A., Hyatt A. D., Green D. E. \& Speare R. (1999) Emerging infectious diseases and amphibian population declines. Emerg. Infect. Dis. 5, 735-48.

Daszak P., Cunningham A. A. \& Hyatt A. D. (2003) Infectious disease and amphibian population declines. Divers. Distrib. 9, 141-50.

Di Rosa I., Simoncelli F., Fagotti A. \& Pascolini R. (2007) The proximate cause of frog declines? Nature 447, E4-E5.

Epstein P. R. (2001) Climate change and emerging infectious diseases. Microbes Infect. 3, 747-54.

Harvell C. D., Mitchell C. E., Ward J. R. et al. (2002) Climate warming and disease risk for terrestrial and marine biota. Science 296, 2158-62.

Hero J. M. \& Gillespie G. R. (1997) Epidemic disease and amphibian declines in Australia. Conserv. Biol. 11, 1023-5.

Ingram G. J. \& McDonald K. R. (1993) An update on the decline of Queensland's frogs. In: Herpetology in Australia: A Diverse Discipline (eds D. Lunney \& D. Ayers) pp. 297-303. Roy. Zool. Soc. NSW, Mosman.

Jennions M. D. \& Møller A. P. (2002) Publication bias in ecology and evolution: an empirical assessment using the 'trim and fill' method. Biol. Rev. 77, 211-22.

Laurance W. F. (1996) Catastrophic declines of Australian rainforest frogs: is unusual weather responsible? Biol. Conserv. 77, 203-12.

Laurance W. F., McDonald K. R. \& Speare R. (1996) Epidemic disease and the catastrophic decline of Australian rain forest frogs. Conserv. Biol. 10, 406-13.

Laurance W. F., McDonald K. R. \& Speare R. (1997) In defence of the epidemic disease hypothesis. Conserv. Biol. 11, 1030-4.

Lips K. R. (1999) Mass mortality and population declines of anurans at an upland site in western Panama. Conserv. Biol. 13, $117-25$.

Lips K. R., Green D. E. \& Papendick R. (2003) Chytridiomycosis in wild frogs from southern Costa Rica. F. Herpetol. 37, 215-18.

Lips K. R., Brem F., Brenes Reeve J. D. et al. (2006) Emerging infectious disease and the loss of biodiversity in a Neotropical amphibian community. Proc. Natl. Acad. Sci. USA 103, 3165-70.

Longcore J. E., Pessier A. P. \& Nichols D. K. (1999) Batrachochytrium dendrobatidis General et sp. nov., a chytrid pathogenic to amphibians. Mycologia 91, 219-27.

Lovejoy T. E. (2006) Protected areas: a prism for a changing world. Trends Ecol. Evol. 21, 329-33.

McCallum H. (2005) Inconclusiveness of chytridiomycosis as the agent in widespread frog declines. Conserv. Biol. 19, 1421-30.

McDonald K. R. (1990) Rheobatrachus Liem and Taudactylus Straughan \& Lee (Anura: Leptodactylidae) in Eungella National Park, Queensland: distribution and decline. Trans. R. Soc. SA 114, 187-94.

McDonald K. R. \& Alford R. (1999) A review of declining frogs in northern Queensland. In: Declines and Disappearances of 
Australian Frogs (ed. A. Campbell) pp. 14-22. Environment Australia, Canberra.

Magurran A. E. (1998) Ecological Diversity and its Measurement. .Princeton University Press, Princeton.

Mahony M. J. (1993) The status of frogs in the Watagan Mountains area of the central coast of New South Wales. In: Herpetology in Australia: A Diverse Discipline (eds D. Lunney \& D. Ayers) pp. 257-64. Royal Zool. Soc. NSW, Mosman.

Mendelson J. R. III, Lips K. R., Gagliardo R. W. et al. (2006) Confronting amphibian declines and extinctions. Science 314, 48-9.

Morehouse E. A., James T. Y., Ganley A. et al. (2003) Multilocus sequence typing suggests the chytrid pathogen of amphibians is a recently emerged clone. Mol. Ecol. 12, 395-403.

Morelle R. (2006) Climate culprit for frog deaths. BBC News Online. [Cited 11 Jan 2006.] Available from URL: http: //news.bbc.co.uk/go/pr/fr/-/1/hi/world/asia-pacific/4602116. stm

Nackagawa S. (2004) A farewell to Bonferroni: the problem of low statistical power and publication bias. Behav. Ecol. 15, $1044-5$.

Oullet M., Mikaelian I., Pauli B. D., Rodrigue J. \& Green D. M. (2005) Historical evidence of widespread chytrid infection in North American amphibian populations. Conserv. Biol. 19, 1431-40.

Pounds J. A., Bustamante M. R., Coloma L. et al. (2006) Widespread amphibian extinctions from epidemic disease driven by global warming. Nature 439, 161-7.

Rachowicz L. J. \& Vredenburg V. T. (2004) Transmission of Batrachochytrium dendrobatidis within and between amphibian life stages. Dis. Aquat. Org. 61, 75-83.

Retallick R. W. R., McCallum H. \& Speare R. (2004) Endemic infection of the amphibian chytrid fungus in a frog community post-decline. PLoS Biol. 2, E351.

Richards S. J., McDonald K. R. \& Alford R. A. (1993) Declines in populations of Australia's endemic tropical rainforest frogs. Pac. Conserv. Biol. 1, 66-77.
Ron S. R. (2005) Predicting the distribution of the amphibian pathogen Batrachochytrium dendrobatidis in the New World. Biotropica 37, 209-21.

Skerratt L. F., Berger L., Speare R. et al. (2007) Spread of chytridiomycosis has caused the rapid global decline and extinction of frogs. EcoHealth 4, 125-34.

Speare R. \& Berger L. (2004) Global Distribution of Chytridiomycosis in Amphibians. Amphibian Diseases Research Group, Townsville. [Cited 14 April 2004.] Available from URL: http://www.jcu.edu.au/school/phtm/PHTM/frogs/ chyglob.htm

Stuart S. N., Chanson J. S., Cox N. A. et al. (2004) Status and trends of amphibian declines and extinctions worldwide. Science 306, 1783-6.

Thomas C. D., Franco A. M. A. \& Hill J. K. (2006) Range retractions and extinction in the face of climate warming. Trends Ecol. Evol. 21, 415-16.

Trenerry M. P., Laurance W. F. \& McDonald K. R. (1994) Further evidence for the precipitous decline of endemic rainforest frogs in tropical Australia. Pac. Conserv. Biol. 1, 150-3.

Watson T. (2006) Vanishing of frogs, toads tied to global warming, study says. USA Today. [Cited 12 Jan 2006.] Available from URL: http://www.usatoday.com/tech/science/ 2006-01-11-warming-animal-decline_x.htm

Weldon C., du Preez L. H., Hyatt A. D., Muller R. \& Speare R. (2004) Origin of the amphibian chytrid fungus. Emerg. Infect. Dis. 10, 2100-5.

Williams S. E. \& Hero J.-M. (1998) Rainforest frogs of the Australian wet tropics: guild classification and the ecological similarity of declining species. Proc. R. Soc. Lond. B 265, 597-602.

Woodhams D. C., Alford R. A. \& Marantelli G. (2003) Emerging disease of amphibians cured by elevated body temperature. Dis. Aquat. Org. 55, 65-7. 